\title{
Hegemonic Formation in Post-Javanese Indonesian Society
}

\author{
Aprinus Salam \\ Center for Research on Culture, Universitas Gadjah Mada, Indonesia \\ Email: aprinus@ugm.ac.id
}

\begin{abstract}
In society, there are various structured power relations that connect individuals who share certain interests and objectives. In these power relations, hegemony plays a significant role. Hegemony is the most important notion in the Marxist tradition, especially as it is conceptualized by Gramsci. This study attempted to re-read the issue of hegemony in the context of ideological contestation in Javanese society in Indonesia. This problem was examined based on post-Marxist theory, especially as it relates to the demolition of the strong order of capitalism. Based on the results, it can be concluded that hegemony forms itself in layers, which influence each other so that there is one area of hegemonic intersection. In Javanese society these days, there is a "competition," especially in Yogyakarta, to return, feel, and become more Javanese than others. The implication is that there are parties who feel more Javanese than others. This case in this study is referred to as the post-Javanese society, although in the intersection area, there are still all-powerful puppeteers.
\end{abstract}

Keywords: hegemony; intersection; ideology; post-Javanese; social formation

\section{INTRODUCTION}

Domination and hegemony are the initial conditions for the formation of society and culture. Domination is a form of cursive power. Meanwhile, hegemony is a soft mastery (i.e., it is often not realized) in power relations between the dominant and the dominated parties (Gramsci, 1971; cf. Singham and Singham, 1973; Sidanius and Pratto, 1999). Society is formed based on these power relations. The formation of relations is possible in various forms, depending on the practical space of the power, and the interests and the objectives of the relationship. The formation of these relations forms the social structure.

In this paper, the community refers to the Indonesian people, so it is necessary to focus on which Indonesian community that is exactly being discussed, as there is great cultural, religious, racial, ethnic, linguistics, educational, and traditional diversity in the country. Therefore, in this study, the community in question is Javanese, specifically the community located in Yogyakarta and its surroundings.
This brief study examines the conditions of the hegemonic formation that wrap up and "control" the Javanese society in Yogyakarta recently. This paper will systematize the answers thus: Firstly, the writing will explain the current condition of the Javanese community in Yogyakarta. Secondly, it will attempt to explain the formation of relations and hegemony that occurred in Javanese society. Finally, the paper seeks to analyze postJavanese society. This study will try to achieve this in the frame of post-Marxist theory, with the help of the relevant postmodern and postcolonial theories. For the purposes of this paper, post-Marxist theory refers to the hegemonic theories developed after Gramsci. In general, Marxians see hegemony in the practices of production relations and structure-based economics (also the controlled production class). What is meant by structure is when a society positions itself, particularly based on social and economic structure (Gramsci, 1971). Post-Marxist theory not only looks at production and economic relations, but 
sees power relations in a broader context, not structurebased, but discourse-based. In this case, what is meant by discourse is a certain verbality that contains ideological values and strengths because it has support, and becomes a part of a greater power (Laclau, 1977).

Similar to post-Marxist theory, postmodern and postcolonial theories are also not structurally grounded. Postmodern theory here refers to trying to understand the development of modernity based on certain criteria so that when a criterion does not become part of modernity, this phenomenon can be called a postmodernity phenomenon. It can be seen from the erosion of grand narratives, the liquidity of identity, and the spread of pluralism, the development of lifestyles and consumerism (Turner, 1994). The need for that explanation is intended to explain the notion of post-Javanese society, that is, when Javanese society has entered a condition that cannot be identified as Javanese in its original sense.

There are many studies on Javanese society in the literature. The most important study is Geertz's (1960; 1998). In the 1950s, Geertz categorized the condition of the Javanese community, which consisted of the abangan, santri, and priyayi communities. There are important differences in these sub-communities and their base hegemonic is seen differently. The abangan and priyayi sub-community bases are identified with strong cultural values. Local values and beliefs coordinate their religion. Meanwhile, what is meant by the santri sub-society is a society whose Islamic religious values coordinate their cultural values. Geertz's study shows the strength of the ideological contestation that hides behind the practices of Javanese life.

Other studies that are relevant to convey are the work of Husken (1998). Based on historical studies, Husken described the social changes in Java from 1830 to 1980 . In his book, he explained that colonialism gave a certain role model in contributing to the changing of the economic system and social stratification of the people in Java. Sumardjan $(1964,1986)$ tried to explain the social changes in Yogyakarta. These books illustrate how much modern education and bureaucracy have changed the formation and government bureaucracy in Yogyakarta. They also illustrate how Javanese society quickly accepted innovation to adapt to the various demands of changing times.

Dove (1988) found out that aspects and dimensions of traditionality in Indonesian society are dynamic and easily adapt to modernity. The traditionality of the Indonesian people does not disturb the development process at all. Thus, traditionality must not be confronted or contradicted with modernity.
Another study of social change in Java during the Japanese occupation is a study by Kurasawa that looked at various programs carried out during the relatively short Japanese occupation of Indonesia against farmers in a Javanese village. The policy involves a program of mobilization (doin) and at the same time imposed strict control (tosei). At that time, the agricultural mechanisms and systems underwent changes due to having to meet the targets in accordance with the orders of the invaders (Kurasawa, 1993). Meanwhile, Hefner (1999) saw changes in the awareness of rural communities due to a perception of themselves as wider citizens and as part of general economic and (national) moral development.

The study of the meaning of social change in Java can also be seen in studies of novels done by Mulder (1985, 2007). Mulder modeled Kuntowijoyo's novel Sermon on the Hill (Khotbah di Atas Bukit) as a tale of disappointment, with various changes that threaten spiritual traditions and values (Mulder, 1985: 77). The conclusion of the study is that Indonesian novels place a person next to the community, where they do not appear to be an integrated role in it or function as parts of the society. According to Mulder, the author gives reasons for the strong pressure to adjust to the current changes of the times (Mulder, 1985: 83).

The thing to be emphasized from some of those previous studies' notes is the various efforts to record and portray the development of Javanese society that continues to move to the present in accordance with the demands of its historical flow. In that track record, it can be seen that the society in Java in general, or Yogyakarta in specific, have moved to the present, with various changes both in the process and format of social relations and formations, at the level of structure, and especially those related to problems when Javanese become modern, when their "Javanese-ness" is decreasing. The anxiety often arises in various formal and informal talks.

Based on these records, this study focuses on the layers of the hegemony of the society in Java (Yogyakarta) dealing with various power relations, be they economic, political, or especially cultural relations. Those layers of relations form a formation. It goes without saying that in the course of modernization and as a postcolonial society, Javanese society shows different developments and layers of "self-perception." This is due to efforts from various parties and interest groups to "manipulate" the community itself for different purposes in order to shape the future society. As a long process of hegemonization, the formation is stored in the "sub conscious," both at the individual and collective levels. 


\section{YOGYAKARTA TODAY}

All societies undergo change. Conditions that cause change include population growth (or lack thereof), development of science and technology, and demands for infrastructure development needs. In its establishment, technological development and integrated capital are in a force called capitalism and modernization (modernism). The world is led to become modern. Not unlike other regions, the society of Yogyakarta has entered and become part of the world community. The question is, what kind of contemporary society exists in Yogyakarta?

Based on tribal composition, the majority (more than $82 \%$ ) of the residents of Yogyakarta are Javanese. Most of them were born and raised in Yogyakarta, but some come from around Yogyakarta, such as Central Java and East Java, and a small portion from West Java. Other residents are from outside Java, such as from Sumatera, Sulawesi, and Borneo. Also, a small part of the society is Chinese, both peranakan (mixed Chinese) and totok (a full-blooded Chinese), Arabic descendants, and others (Woodward, 2011; Beatty, 1999).

Not surprisingly, there are many communities in Yogyakarta, both those that are not politically and economically affiliated or affiliated with the power structure. Although it is not a new or distinct symptom, there is a fact that connections in Yogyakarta are not just kinship-based, but also based on economic interests, hobbies, education, profession, and so on. Communities or groups affiliated politically and economically are relatively easier to "control." This is related to the dependent position of the community vis-à-vis formal power, both the power of the local government (and also the position of the privileges of the Sultanate and Pakualam) and those affiliated to certain political or social organizations.

Very rarely does a person only have one community in the above sense. There are many community members who also take part in various other communities' activities that are not directly related to the formal organizational power structure. These communities are usually more independent. The art community or the community of a particular hobby, for example, is usually relatively more independent even though there is a hierarchy in it, but the hierarchy is only internal. Thus, the structure of economic and political power is not fully applicable to all members of society (cf. Anderson, 1990). In this position, the issue of the power of discourse plays an essential role.

These days, many starred luxury malls and hotels are being built in Yogyakarta If modernity can be measured by its physical symbols, then it is clear that Yogyakarta has are experiencing development and a relatively rapid modernization process. The Provincial Statistics Bureau has stated that approximately 4 million tourists (both domestic and international) visited Yogyakarta in 2012, and that number increased to more than 4.8 million in 2017 (BPS, 2018). It is reported that the number of tourists visiting Yogyakarta since 2015 is more than the population of Yogyakarta itself, which in 2017 was $3,587,921$. From their appearance, most of Yogyakarta society has experienced a process of modernization with appearances that qualify as modern humans along with those who appear to be very religious. In this context, Yogyakarta society is ambiguous. On the one hand, they are eager to be part of modern society, but on the other hand, there is anxiety that modernity increasingly erodes traditional values and especially Javanese values.

With respect to the above ideas, there are various practices, policies, or activities that differ from one another. Tradition-based activities, such as art, carnivals, ketoprak, wayang, dance, or rituals such asmerti, slametan, and so on, run parallel to various modern activities. These activities overlap in and with religious activities, both in terms of social rituals, activities within the framework of national programs, and even in economic and political terms.

These various overlapping social practices, from the point of view of those who adhere to tradition, are considered far from the original compared to those in the past, especially Java, which was imagined during the $18^{\text {th }}$ to $19^{\text {th }}$ centuries. There were at least four groups in framing the case. Firstly, those who are not sufficiently pleased with the living practices of the Javanese who are farther away from native Java. Secondly, those who consider these changes to be normal and live as Indonesian citizens. Thirdly, those who see tradition as a practice of life that deserves to be developed creatively in various ways. Fourthly, those who break away from tradition and live as citizens based on a particular religion or become modern citizens.

It is not the diversity of life practices that are the object of attention, but the variants of ideological intersections in seeing the world that are the background of citizens as well as cause differences in various life practices. That difference in the ideological intersection will be a complicated conversation if the factors of religion, gender, education, age, and ethnicity are mapped one by one and related to various problems that arise at the level of social life. As another example, a new generation known as "millennials" is now emerging and giving an indication of different lifestyles and views, namely, the emergence of a shorter memory due to spending more time in online spaces. 
In practice, there are two types of opposition, stiff opposition, and soft opposition. Stiff opposition arises in various conflicts, such as ethnic and/or religious conflicts. Soft opposition arises in various verbal quarrels, either directly or through social media. These quarrels can usually be resolved, both in the name of politics and especially in the name of cultural deliberations. The position of the Yogyakarta Sultanate still plays an important role in managing and reducing those various situations of conflict. The position of the Sultanate is what distinguishes Yogyakarta from several other regions, especially at the provincial level.

\section{HEGEMONIC AND SOCIAL FORMATIONS}

One of the important causes of the condition in Yogyakarta as described above is the existence of discourse competition (more explicitly, ideology), which contests continuously (Bonnin, 2017; Woodward, 2011). There are at least four important ideologies that have become the arena of discourse contestation, namely nationalism, traditionalism, religiousism (religionism), and modernism. In addition to those four, there are other ideologies that need to be taken into account, such as socialism, or even Pancasilaism. However, in the case of Yogyakarta, this study shows that these two ideological matters are temporarily ignored because, as will be explained later, they have been implicitly accommodated in the four ideological contestants.

Ideology does not run alone in different paths. What that often happens is that there are inter-ideological relations in the same path (cf. Laclau, 2005). What is meant here by relations are coordinative, subordinative, and contradictory relations. This ideological relation led to an intersection, or rather, what was later referred to as hegemonic formation, which had implications for social formation. A person is not only hegemonized by one ideology, but by many ideologies that in practice can appear together or alternately.

The first thing to say is that nationalism in relative terms does not contradict its various competitors. Nationalism does not build a system of values and knowledge that can be contrasted with others. Sometimes there is a debate when there are people who are not considered nationalists because they are believed not to love their nation. However, this assessment is not fully true. In the practice of living as a Javanese, nationalism is inherent in traditional practices, so it is not reasonable to say that people who practice their Javanese-ness are considered not nationalist enough.

Religiosity is believed to contain "international" values. However, an internationalist can still be a religious person, just as a modernist can remain a religious person (Ronald and Norris, 2004; Aoki and Berger, 2002; Tamney, 1980). As explained later, the opposite between religiosity and modernism lies at the level of "Being," and the "External" reality that later causes modernism to be called secular and thus contrary to religious belief. This paper will not go further into that discussion. Simply put, at the "surface" level, conflicts always arise in the practice of everyday life.

Traditionalism is relatively contrary to modernism but can be friends with religion and nationalism. In some cases, a nationalist person can be a religious and traditionalist at the same time (Berger, 2012). At a certain level, it is very possible that that person will become a modern citizen, but the principles of tradition and religiosity are his or her deepest beliefs. Modern citizenship is more about following the rules of the game and the modern behavior itself, but does not operate in the area of ideological beliefs, in the sense that the degree of the hegemony of its modernism is not firmly entrenched in traditionalism (cf. Voas, and Crockett, 2005).

However, this form of conflict does not usually emerge as a weapon. The Javanese, in their differences, always adhere to the concept of harmony, maintaining differences in diversity. Various differences in beliefs and values of life even become a joke. However, this difference does not cause violence. Itis different if it is related to material ownership issues, such as land, houses, inheritance, and so on. This was also a precedent for the emergence of the post-Javanese society, in the sense that the symptoms of differences in beliefs and perceptions of their Javanese-ness did not actually become a precedent for the emergence of violence in Javanese society.

There are several reductions in describing the contradictory relations above. This paper tries to give a rough picture of the formation of hegemony and the social formations it constructs. Therefore, a general and reductive explanation of coordinative and subordinate relations also becomes an important part in explaining hegemony formation. This is related to some of the more basic precedents that the people of Yogyakarta, as the center of Javanese culture, have an active Sultanate and Pakualaman, causing coordinative and subordinate relations to be very important. Among the four qualities, religiosity occupies the strongest position (Geertz, 1960; Purwani, 2016). This is due to ideological promises about the "end" of life, the life "outside" the life, something that cannot be and is not promised by the other contestants. Religion keeps the unconscious desire for the purpose of life itself. However, in practice, 
humans live in their "consciousness," in the space of their ego. In this ego space, various other forces play and intervene, especially from its value and symbolic aspects that life must factually be carried out. In this case, "Javanese religiosity" does not promise the end of life in a verbal language such as merit, heaven, or hell. However, there is a world of hening (silent) and wening (purity) outside the human world that has been waiting for humans to behave in accordance with the demands and vocation of their religious traditions.

In Javanese society, traditionalism subordinates the religion (Geertz, 1960; Hefner, 1985; Woodward, 2011). However, as already alluded to, religions offer promises that are contrary to modernism/capitalism. Where is the meeting point? The meeting point, and at the same time become the intersection area, is in the border space occupied when trying to rationalize together that whatever happens, life must be lived. Not surprisingly, what happened was like an enemy in a blanket, walking in the same room, but as if they were spying on each other. The practice of this reconnaissance in Javanese society takes place in silence and does not interfere with anything else. If there is a case of intolerance, such as the destruction of offerings and other ritual offerings (this has happened several times, such as that happened in harvest ritual in Bantul region), then the impulse occurs because of the influence of a particular religion, not because of the value of its Javanese tradition-religiosity (Woodward, 2011; Tambiah, 1979).

For Javanese, traditionalism and nationalism always seem to get an injection from religiosity, gaining important positions in the relationship space (Hefner, 1985). In that relational context, traditionalism, sometimes occupies a contradictive position with modernism; although they go hand in hand, they are in a position of mutual dislike. Ideologically, there is no difference in their fundamental promises because traditionalism, modernism, and even nationalism are not oriented to one life "out there." However, the ideological values and symbols of modernism/capitalism already occupy positions of power, so they have the power to regulate worldly life.

One of the contestants that has power because of the promise of its "worldly" exploration and enjoyment is capitalism, which collaborates inherently with modernism (Dove, 1988; Geertz, 1968). In the practice of life, this contestant collaborates, even exploited in tandem with other powers of discourse, with a system of power in its various forms, such as political, economic, social, and cultural power. This contestant, we know, becomes a great power, in which we live, like it or not. This contestant is even able to trade other contestants, mainly because of the strength of its capital.

A further problem is how to describe the formation of hegemony (formation of ideological relations) in that intersection space. As a Javanese, the deepest subconscious space is the tradition(alism). It coincides with local beliefs and myths, so that this construct appears in the symbolic spaces of the abangan community as practices that promote the mental/psychic process. This practice does not usually run parallel with Sharia religion. In the $14^{\text {th }}$ and $15^{\text {th }}$ centuries, Java underwent Islamization. Although in most cases Islam became Javanese, later came the religious/santri community, which was centered in Islamic boarding schools (pesantren). The santri community is directly connected to the center of Javanese culture (Keraton Kesultanan Yogyakarta/Yogyakarta Sultanate) (Geertz, 1968).

This layer of consciousness and subconsciousness, in further development, succumbed to the temptation as a colonized society, which later recognized the process of colonial capitalism and colonial modernization, which later transformed into modernism and postcolonialism (cf. Anderson, 1990). Indonesian society has been classified as an indigenous community, a class of people under the Far East, incorporating both Indo and Western communities. In the long run, processes began when Javanese underwent Westernization and modernization (Husken, 1988; Hefner, 1985). As a community with discourse deposits, of course, the process of Westernization and modernization is not entirely successful. There will be various groups of people whose hegemonic processes vary. This causes groupings in society. The groupings are based on the difference in experiencing more specific distinctions, namely differentiation and grouping of economic, religious, and more specific interest classes. Under these conditions, various faith-based, class-based, and sub-sub-cultural communities emerged which acted in the name of their love for tradition (Husken, 1988). Further developments show that the tradition base is also different in orientation. This will be explained further in the next section.

\section{POST-JAVANESE SOCIETY}

Considering the above explanation, the formation of relations influences social grouping in society. Yogyakarta society experiences a layered hegemony segregation stage and differs in composition. Itis determined by one's position in the social structure, including class, ethnic/ race, gender, economic class, religion, and education positions (Ivie, 2015). These things will determine the 
insistence and encouragement of discourse that will become their daily consumption. Even geographic structures and conditions determine how a person is then constructed by a discourse algorithm that builds one's awareness.

Ignoring the influence of such diverse positional variables, this paper limits its study only by looking at communities. There are several ways to "differentiate" the existence of the community. The first method is that in relation to the power structure, there are at least three categories of community. First, the community that has a direct connection with the (regional) government, including the power of the Yogyakarta court; second, a community that does not have a direct connection with the government and the Keraton power, but possesses a strong economic and political base; and third, a community that has no direct connection with the power of the government or the kingdom and does not have a strong economic base.

It can be expected that communities with connections to power are dominant. Civil servants, institutions and social or political organizations, and everything related to the palace occupy a dominant position, both administratively and coordinatively. The control of power institutions (regional government and Sultanates) as well, with its economic and political power, discourse and program the various activities of preservation, establishment, development, and utilization of culture, can be seen in the cultural establishment and development documents of Yogyakarta. As the center of Javanese culture, these power lines show Yogyakarta's differences compared to other cultural regions.

The strength of the existence of the Keraton and the regional government, which was implemented by the Culture Service, the Education Office, and several other related offices, provided a coordinative influence to many arts and cultural communities. This process, both of which was originally just "in order to" and because of administrative and economic dependence, caused activities with the aroma of tradition to become prominent. Of course, it is possible that other activities are not traditional in nature. However, it will be lower on the priority scale so that many modern communities do not get its proper place.

It needs to be understood that the "direct network" with power is a big source of capital to do many social, political, or art-cultural activities and practices. The messages of "Javanese-ness" and the feeling that they own the most of Yogyakarta - it cannot be denied - are one of the important issues that are present in a contradictory manner, so that the expressions of Yogya Ora Didol
(Yogyakarta is not for sell), etc. are contradictory expressions used by various parties, not only as a resistance but also a commodity. It cannot be said about the positive or negative side of that contradiction because the estuary of the debate is power itself (cf. Behrend, 1980).

Another community differentiation can be achieved by looking at the basis, whether based on religion, profession, ethnicity, hobbies (including art and literature), even based on economic class. Thus, many communities exist in society. One can be ascertained not only in a particular community, but at least in more than one. In fact, the diversity of these communities has shown the diversity of relation formation and implicitly, the diversity of hegemonic intersections.

Every community has its own ways of appearing and existing in society (Laclau, 1977; 2005). The situation is now very much supported by social media, so that each community and its members have the same opportunity to share and upload the community activities on social media. Many communities perform various ceremonial activities, rituals, and various other events, for the sake of the existence of the community itself. For people in Yogyakarta, the level of activity is also different, ranging from the RT/RW level to the national level, or the school level to the larger class level. Not many are aware that the community that someone is involved in, as weak or as strong as any, actually has a goal and is fighting for something.

Based on the explanation of hegemonic formations, in this context, the important thing is the issue or theme that is carried out in various community activities (Gramsci, 1971; Mulder, 1985). What attracts the people's attention is an issue or theme that carries tradition. Tradition is displayed and re-actualized in a variety of ways and events, whether it is just a small ceremony or various activities categorized as an action that involve the masses, such as carnivals. These action activities, by carrying out various practical practices (merti), revive traditional arts, through various appeals or even regulations at the local government level, such as on certain days they wear traditional/regional attire and speak Javanese.

The practice of re-traditionalization and reactualization of tradition is a strategy to reinforce national culture, as a way of showing the diversity of regional culture and a kind of multiculturalization of nationalism (Schlehe, 2017; Woodward, 2011). The carnival that often airs is the best example of how various practices and beliefs appear in the name of freedom of expression. This event shows that the popular belief (common sense) about "serving the country," which is considered nationalist 
behavior, is the ripple that spring up "irregularly." It once again represents the formation and intersection of hegemony that occurs within the community.

With various policies and re-actualization movements and traditionalization, other life systems continue to develop. Simultaneously, Yogyakarta moved quickly into a modern city and a capital. In overlapping movements and activities, theoretically, there are no activities that do not require facilitation of modernity and capital. Various traditional activities become important and attract attention when held and polished by modernism and capitalism. They appear at the center and become the modern and capitalist symbols. Modernized public spaces are also an important choice to represent tradition (Schlehe, 2017).

This does not mean that the condition is unknown by Yogyakarta society. That is also the reason why many Yogyakarta society is not "happy" with the situation (Woodward 2011). It must be admitted that much Yogyakarta society has become modern, or on the other hand, become political or economical. In this situation, an expression the Javanese who loses their Javanese-ness, the Javanese who are no longer Javanese, is an expression of anxiety about the loss of something that is thought to exist, which is called "native Java." The search for authenticity is an important issue that cannot be avoided.

The issue is that there is a competition for who is the most Javanese, less Javanese, and not Javanese (Yusuf, 2013). In some discussions, for example, some expressions, such as Jawa ngawur (insane Javanese), Jawa yang tidak njawani (Javanese who are not like the Javanese), Jawandeso (provincial Javanese), very Javanese (Jawabanget), Jawaajaran (knowledgable Javanese), Jawa modern (modern Javanese), and so on are used. Both authentic and non-authentic Javanese identities are also associated with board symbols of tastes for clothing, food and housing, and various other symbolic aspects which are considered to be typical of Javanese such as possession of keris or heirlooms.

Such condition of internal competition is called post-Javanese (Gramsci, 1971; Laclau, 1977; Turner, 1994). What is meant by post-Javanese is when there is a contestation of fellow Javanese to determine the legitimacy of who is the most Javanese or native Javanese, and who is less Javanese. In that competition, the interesting thing is that the background or religious differences are not important. To feel and become more Javanese, one can be from any religious background. This is certainly important to note that becoming more Javanese is not related to religion. A Catholic or a Muslim has the same opportunity to feel more Javanese or native Javanese.
The answer to the problem is found into a deeper intersection layer. There are two ways about the meeting point why religion is not a coordinative thing in the hegemonic intersection. The meeting point is in the dimension of spirituality or the dimension of holiness (Note: this explanation is inspired by a book by Asef Bayat, 2007). The meeting point in both dimensions is possible when religion is released from its Sharia dimension. That is why the existence of the native Javanese does not require a person to be syar' $i$ in his religion. The direction of the spiritual and holiness dimensions still needs a deeper study because the implications of both directions will lead to different estuaries. The following explanation is more hypothetical than empirical.

A spiritual dimension is a conditional level that frees a person or a society from their symbolic ideological rules and emphasizes the aspect of transcendence (path of makrifat) to the existence of the Supernatural (Yusuf, 2013). This is different from the dimension of chastity. Chastity is a conditional level that requires a person or society to be free from things that are impure, free from defiling things. That means holiness is different from spirituality. The thing that is not conducive from the dimension of holiness is the demand that a person or society fulfill the ideological rules which are called sacred (clean) and which are not clean (defiled/dirty).

Both of these dimensional forces are currently competing for a greater space. Which dimension will play a bigger role still cannot be expected. However, in some countries, for example, Morocco, Sudan, Syria, Pakistan, and Iran, with a variety of different conditions, the situation changes the direction, with examples of failure when purity becomes the dimension that is trying to be confirmed (Bayat, 2007; Geertz, 1968). There will be resistance from the parties issued by the dimension of holiness because there are parties who are considered impure, not genuine (dirty/polluted). Moreover, the paradigmatic building of purity claims is considered to have never succeeded in convincing others other than the claim itself. The claim is ideological, so that competition is possible to appear on the surface level in various conflicts.

Unlike this, spirituality does not claim purity, so that no one feels removed by that dimension. In a spiritual space, one does not need to feel pure. The problem is, retraditionalization or revitalization of tradition demands more dimensions of spirituality or holiness. If authenticity is meant in the original Javanese concept, it is intended to re-cleanse the defiling things, which makes the Javanese no longer Javanese.

Does the dimension of spirituality have a concept 
of people equal to native Java? As already mentioned, spirituality is a transcendent path or process to walk into a supernatural existence. That means spiritual Javanese are Javanese who try to become Javanese. He did not demand to get the native Javanese title, but it is enough that this person learns continuously to be a Javanese.

Apart from all that, the great power in the structure of life, such as the forces of modernism and capitalism, have been portrayed as masterminds who play these important roles and contestations (Gramsci, 1971). The great mastermind even succeeded in making native Javanese, people who were no longer Javanese, and people who continued to learn to be Javanese, consciously or not, become agents of the great system that we would inevitably live and depend on in the system and structure. At the symbolic level, tradition and traditionalism have become commodities themselves.

\section{CONCLUSION}

Based on the description above, several things can be concluded. Firstly, the society of Javanese Yogyakarta is one that experiences various compositions of discourse and in a manner (behavior) in which they can coexist side-by-side. However, this does not mean that there is always the possibility of competition for domination and hegemony. Forms of the competition may or may not lead to violence; the situation depends on hegemonic formation in its citizens.

Secondly, the society of Javanese Yogyakarta, in its various forms, has experienced considerable modernization. This caused one process to distance the society of Javanese Yogyakarta from their Javaneseness. That is why resistance emerges from two directions, namely traditionalism on the one hand, and religiousism on the other. This article has mainly highlighted the resistance from traditionalism, by showing the emergence of the discourse and movement to return to Java, which is considered more authentic.

Thirdly, with the strengthening of the existence of traditionalism discourse, there are also sporadic discourse and competition movements within Javanese society for one to be seen as more Javanese than others. This condition is referred to as a post-Javanese symptom, in which there are a number of longings to "restore" the society to what it was before, and into something that is considered "authentic." However, this strategy and political culture will never succeed because it does not have historical support. Various formations of hegemony have made it impossible to unravel the formation in the format of Javanese society, which is considered more authentic.

\section{REFERENCES}

Anderson, Benedict R.O'.G. (1990). Language and Power: Exploring Political Cultures in Indonesia. Cornell University: Cornell University Press

Aoki and Berger (2002). Many Globalization: Cultural Diversity in Contemporary World. Oxford University Press.

Bayat, Asef. (2007). Making Islam Democratic: Social Movements and the Post-Islamist Turn. Stanford, California: Stanford University Press.

Behrend, T. E. (1980). Kraton and cosmos in traditional Java.Madison: University of Wisconsin.

Berger, Peter L. (2012). Further Thoughts on Religion and Modernity. Sociology, 49, 313-316. DOI 10.1007/ s12115-012-9551-y

Bonnin, Juan Eduardo (2017). Dissent, Protest and Resistance: Discourses of Contestation and Mental Healthcare in Buenos Aires. Javnost-The Public, 24(3), 218 234, DOI: $10.1080 / 13183222.2017 .1306192$

BPS. (2018). Hotel Occupancy Report in Yogyakarta. Yogyakarta: BPS.

Dove, Michael R. (1988). Traditional Culture and Development in Contemporary Indonesia, in Michael R. Dove (Ed.). The Real and Imagined Role of Culture in Development, Case Studies from Indonesia. Honolulu: University of Hawaii Press.

Geertz, C. (1960). The Religion of Java. University of Chicago Pres.

Geertz, C (1968). "Religion as a Cultural System." In Anthropological Approaches to the Study of Religion. Ed. Michael Banton. pp. 1-46. ASA Monographs, 3. London: Tavistock Publications.

Gramsci, A. (1971). The Selection of Prisons Noted Book. New York: International Publishers.

Hefner, Robert W. (1985). Hindu Javanese: Tengger Tradition and Islam. Princeton: Princeton University Press.

Husken, Frans. (1998). Masyarakat Desa dalam Perubahan Zaman: Sejarah Deferensiasi Sosial di Jawa 19301980. Jakarta: Grasindo.

Inglehart's Ronald, F. and Pippa Norris (2004). Sacred and Secular: Religion and Politics Worldwide. Cambridge University Press.

Ivie, Robert Lynn (2015). Enabling Democratic Dissent. Quarterly Journal of Speech, 101 (1), 46-59.

Kurasawa, Aiko. (1993). Mobilisasi dan Kontrol: Studi Tentang Purubahan Sosial di Pedesaan Jawa 19421945. Jakarta: Yayasan Karti Sarana dan Gramedia.

Laclau, Ernesto (1977). Politics and Ideology in Marxist Theory. London: NLB.

Laclau, Ernesto (2005). On Populist Reason. London: Verso. Mulder, Niels (1985). Pribadi dan Masyarakat di Jawa. Jakarta: Sinar Harapan. 
Mulder, Niels (2007). Doing Java: An Anthropological Detective Story. ATF Press.

Purwani, Ofita (2016). Javanese cosmological layout as a political space. Cities, 61, 74-82. Doi: http://dx.doi. org/10.1016/j.cities.2016.05.004

Sidanius, Jim, Pratto, Felicia (1999). Social Dominance: An Intergroup Theory of Social Hierarchy and Oppression. Cambridge: Cambridge University Press.

Singham, A.W. and N. L. Singham (1973). Cultural domination and political subordination: notes towards a theory of the caribbean political system. Comparative Studies in Society and History, 15(3), $258-288$

Schlehe, J. (2017). Contesting Javanese traditions. The popularisation of rituals between religion and tourism. Indonesia and the Malay World, 45(1), 3-23.

Soemardjan, Selo and Soelaeman. (1964). Setangkai Bunga Sosiologi. Jakarta: Lembaga Penerbit Fakultas Ekonomi Universitas Indonesia.
Sumardjan, Selo (1986). Perubahan Sosial di Yogyakarta. Yogyakarta: Gadjah Mada University Press.

Tambiah SJ. (1979). A Performative to Ritual. London: The British Academy and Oxford University Press.

Tamney, Joseph, B. (1980). Functional Religiosity postmodern sociology. Sociology Anal, 41, 55-65.

Turner, Bryan S. (1994). Orientalism, Postmodernism, and Globalism. London: Routledge.

Voas, David, and Alasdair Crockett (2005). Religion in Britain: Neither Believing nor Belonging. Sociology, 39(1), 11-28. DOI: 10.1177/0038038505048998

Woodward, M. (2011). Java, Indonesia and Islam, Muslims in Global Societies Series. Springer.

Yusuf, M. (2013). When Culture Meets Religion: The Muludan Tradition in the Kanoman Sultanate, Cirebon, West Java. Al-Albab, 2(1), 19-31. 